\title{
Fungsi Controlling dan Evaluasi Kepala Sekolah Terhadap Kinerja Guru di SMPN 1 Lembar Lombok Barat
}

\author{
Saryati ${ }^{1}$, Abdul Sakban² \\ ${ }^{1}$ Pendidian Pancasila dan Kewarganegaraan, Universitas Muhammadiyah Mataram, saryati12@gmail.com \\ ${ }^{3}$ Pendidian Pancasila dan Kewarganegaraan, Universitas Muhammadiyah Mataram, sakban.elfath@yahoo.co.id
}

INFO ARTIKEL
Riwayat Artikel:
Diterima: 23 September
2020
Disetujui: 30 September
2020

Kata Kunci:

Kepala sekolah

Controlling

Evaluasi

Kinerja guru

\begin{abstract}
ABSTRAK
Abstrak: Kepala sekolah memiliki dua fungsi pokok yaitu sebagai controlling dan evaluasi terhadap kinerja guru, siswa dan mutu sekolah. Tujuan penelitian ini adalah untuk mengetahui fungsi controlling dan evaluasi kepala sekolah terhadap kinerja Guru. Penelitian merupakan penelitian kualitatif. Subjek penelitiannya adalah kepala sekolah, wakil kepala sekolah, dan Guru kelas SMPN I Lembar Lombok Barat. Metode pengumpulan data yang digunakan observasi, wawancara, dan dokumentasi. Data yang diperoleh kemudian dianalisis dan disajikan kembali atau direduksi data kemudian ditarik kesimpulannya. Hasil penelitian ini menunjukkan bahwa fungsi controlling kepala sekolah yaitu melakukan pengawasan terhadap kedisplinan waktu, mengawasi guru yang sering absen sekolah, mengecek perangkat pemebelajaran, melihat cara guru membangun komunikasi dalam lingkungan sekolah, baik itu sesama guru maupun dengan siswa sarana dan prasarana sekolah. Karena dengan adanya sarana yang memadai mampu menunjang keberhasilan dalam melakukan pembelajaran. Untuk mengevaluasi kinerja guru, peran kepala sekolah mengacu pada prinsip evaluasi yaitu menilai kemampuan guru dalam menerapkan semua kompetensi dan keterampilan yang diperlukan pada proses pembelajaran, pembimbingan, atau pelaksanaan tugas tambahan yang relevan dengan fungsi sekolah/madrasah. Jadi kepala sekolah memiliki tugas untuk menilai kinerja baik buruknya bawahannya dan memiliki peran penting untuk meningkatkan mutu sekolah dengan mengevaluasi secara berkala.
\end{abstract}

\begin{abstract}
The principal has two main functions, namely controlling and evaluating the performance of teachers, students and school quality. The purpose of this study was to determine the controlling and evaluation functions of school principals on teacher performance in SMPN 1 Lembar West Lombok. This research is a qualitative research. The research subjects were the principal, vice principal, and class teachers of SMPN I Lembar West Lombok Data collection methods used observation, interviews, and documentation. The data obtained is then analyzed and restated or the data is reduced and conclusions are drawn. The results of this study indicate that the controlling function of the principal is to supervise time discipline, supervise teachers who are often absent from school, check learning devices, see how teachers build communication in the school environment, both with fellow teachers and with students of school facilities and infrastructure. Because with adequate facilities capable of supporting success in learning. To evaluate teacher performance, the role of the principal refers to the principle of evaluation, which is to assess the ability of teachers to apply all competencies and skills required in the learning process, mentoring, or the implementation of additional tasks relevant to the school / madrasah function. So the principal has a duty to assess the good and bad performance of his subordinates and has an important role in improving the quality of the school by evaluating it regularly.
\end{abstract}

\section{A. LATAR BELAKANG}

Untuk mendukung agar terpenuhinya pendidikan yang berkualitas, pemerintah menyelenggarakan pendidikan yang memadai bagi setiap warga negara untuk menunjang kehidupannya. Dilihat dari faktor penunjang yang dapat mempengaruhi pendidikan diantaranya adanya fasilitas, pendanaan, kurikulum, pengadministrasian, dan tenaga pendidikan. Dari semua faktor penunjang tersebut merupakan komponen terpenting dalam melaksanakan proses pendidikan. Diantara kesemua faktor penunjang tersebut, tenaga pendidik merupakan komponen yang paling penting dalam menentukan proses jalannya sebuah pendidikan yang berkualitas. Melalui upaya-upaya yang telah dilakukan pemerintah tersebut diharapkan guru mampu menjalankan pekerjaannya dengan profesional sehingga diharapkan mampu mengubah kondisi masyarakat kearah yang lebih baik. Pendidikan merupaka sebuah langkah yang paling efektif untuk mengubah keadaan 
masyarakat khususnya generasi muda agar tidak tertinggal saing dengan negara lain khususnya dalam dunia pendidikan. Oleh karenanya seorang pendidik sangat diperlukan dalam halnya menjalankan tugasnya dengan baik. Untuk melihat baiknya kualitas dari tenaga pendidik dapat dilihat melalui kinerja yang dihasilkannya.

Penelitian sebelumnya menemukan peran kepala sekolah sebagai manajer dilakukan dengan menerapkan prinsip-prinsip manajemen yang meliputi Planning (Perencanaan), Organizing (Pengorganisasian), Actuating (Penggerakan), Controling (Pengawasan).[1] Peran kepala sekolah dalam monitoring dan evaluasi meliputi monitoring siswa dari mulai proses seleksi sampai selesai, prestasi sekolah baik akademik maupun non akademik, peng-awasan terhadap PBM dengan instrumen mengacu pada PKG dan PKB, memantau pembelajaran di kelas. Hambatan yang ditemukan disiplin kerja dan belajar masih kurang, miskomunikasi,, penggunaan dana BOS tidak tepat sasaran, perlu masukan dari stakeholder.[2] Kepala sekolah sebagai manajer merumuskan program kebijakan melalui perumusan visi, misi dan tujuan sekolah telah dilakukan dengan melibatkan seluruh komponen sekolah, juga memperhatikan kebutuhan lingkungan untuk peningkatan mutu pendidikan. Strategi dalam meningkatkan mutu pendidikan melibatkan guru-guru, wakil kepala sekolah, tenaga tata usaha serta masukanmasukan dari pihak komite sekolah.[3] Mutu pendidikan disekolah sangat tergantung managemen kepala sekolah dalam mengembangkan.[4] Peningkatan mutu pendidikan adalah melakukan pemantauan, evaluasi secara terus menerus terhadap keberhasilan program yang telah ditentukan, perencanaan dan penyusunan rencana kata yang disepakati dengan peningkatan kebutuhan mutu pendidikan yang berorientasi pada misi sekolah, komunikasi intensif dengan guru, siswa, orang tua siswa dan masyarakat.[5];[6] Kepala sekolah mampu menjalankan tugasnya sebagai supervisor dan administrasi dengan baik,[7]

Berdasarkan beberapa penelitian sebelumnya lebih banyak menjelaskan aspek penerapan manager kepala sekolah, strategi, meningkatkan mutu pendidikan melalui peran kepala sekolah, kepala sebagai supervisor dan administrasi. Sementara penulis memfokuskan pada penelitian berkaitan dengan peran kepala sekolah sebagai manajer dalam fungsi Controlling dan evaluasi untuk meningkatkan kinerja guru di SMPN I Lembar kabupaten Lombok Barat. Dengan mengacu pada teori Leslie W. Rue dan Liody L. Byars[8] yang menejelaskan terdapat lima aktivitas dasar yang dilakukan oleh seorang manajer yaitu plnning, Organizing, Staffing, Leading,Controlling.

Kepala sekolah berfungsi sebagai controlling dan evaluasi merupakan strategi untuk menilai konerja guru dalam proses belajar mengajar maupun meningkatkan mutu pendidikan di sekolah.

Kinerja dapat diartikan sebagai suatu pelaksanaan tugas maupun hasil dari pekerjaan yang telah dilakukan seseorang. Kinerja merupakan hasil kerja secara kualitas dan kuantitas yang dicapai oleh seorang pegawai dalam melaksanakan tugasnya sesuai dengan tanggung jawab yang diberikan kepadanya.[9] Kinerja dapat diartikan sebagai apa yang dikerjakan atau tidak dikerjakan oleh seorang karyawan dalam melaksanakan tugas-tugas pokoknya.[10]Hal ini dapat diartikan bahwa apa yang telah dilakukan seseorang dalam bekerja dapat terlihat dari hasil kerjanya.

Untuk menunjang keberhasilan sebuah pendidikan maka guru dituntut utuk memiliki kinerja yang baik. Hal ini dikarenakan guru merupakan tenaga pendidik yang diakui keprofesionalannya. Kinerja guru dapat terlihat pada kegiatan merencanakan, melaksanakan, dan menilai proses belajar mengajar yang intensitasnya dilandasi etos kerja dan disiplin profesional guru.[11] Kinerja guru meliputi merencanakan, mengelola pelaksanaan, menilai proses dan hasil, mendiagnosis kesulitan belajar, dan merevisi program pembelajaran.[12] Dengan demikian bahwa kinerja guru dapat dilihat dari pelaksanaan guru dalam merencanakan pembelajaran, melaksanakan pembelajaran, dan mengevaluasi pembelajaran.

Sehingga apabila guru telah melaksanakan kegiatan perencanaan, pelaksanaan, maupun evaluasi pembelajaran dengan baik dan sesuai aturan yang telah ditentukan maka guru tersebut dianggap memiliki kinerja yang baik. kejadian dilapangan menunjukan sangat memprihatinkan dikarenakan masih banyak guru yang tidak memiliki kinerja yang baik. Dalam aspek perencanaan pembelajaran masih banyak guru yang hanya menjiplak hasil perencanaan pembelajaran orang lain. Padahal seharusnya semua perangkat pembelajaran harus dibuat sendiri berdasarkan karakteristik dan kebutuhan peserta dididk. Dalam aspek pelaksanaan pembelajaran masih ditemukan guru yang belum disiplin dalam bekerja seperti terlambat masuk kelas dan mengakhiri kegiatan belajar mengajar lebih cepat dari waktu yang ditentukan.

Selain itu guru juga masih kurang kreatif untuk menyusun strategi pembelajaran yang efektif dan menciptakan media pembelajaran yang menarik dan tepat untuk siswa..Guru lebih sering menggunakan metode pembelajaran monoton dan membosankan bagi peserta didik. Dalam aspek evaluasi pembelajaran guru lebih sering menggunakan sistem evaluasi pembelajaran dengan tes tertulis dibandingkan sistem evaluasi pembelajaran yang lain. Padahal guru dapat memilih sistem evaluasi pembelajaran lain yang sesuai dengan kebutuhan siswa dan materi yang sedang diajarkan.

Agar proses pendidikan dapat berjalan efektif dan efesien, guru dituntut memiliki kompetensi yang 
memadai. Namun ketika delihat untuk menjadi guru yang memilki kinerja yang baik tidaklah mudah, disinilah peran kepala sekolah dibutuhkan untuk nmenunjang kinerja seorang guru profesonal. Karena kepala sekolah merupakan manajer yang menentukan jalannya dari sebuah organisasi yang menjadi tanggung jawabnya sebagai kepala sekolah. Salah satu tugas penting yang harus dijalankan kepala sekolah yaitu meningkatkan kinerja guru agar bisa manjadi guru yang profesional dalam menjalankan tugasnya.

Dalam perspektif kebijakan pendidikan nasional terdapat tujuh peran utama kepala sekolah yaitu, sebagai: (1).Edukator, (pendidik), (2) manajer, (3) administrator, (4) supervisor, (5) Leader (pemimpin), (6) pencipta iklim kerja, dan (7) wirausahawan.[13] Dalam mengelola tenaga kependidikan, salah satu tugas kepala sekolah sebagai manajer yang harus dilakukan adalah melaksanakan kegiatan pemantapan dan pengembangan profesionalitas para pendidik. Sehubungan dengan hal tersebut, kepala sekolah harus lebih memperhatikan bawahannya dengan cara memberikan kesempatan yang seluas-luasnya kepada bawahannya untuk mengembangkan kinerjanya melalui peningkatan kompetensi dan pelatihan-pelatihan yang mampu menunjang kualitas bawahannya/tenaga pendidik.

Kepala sekolah denagn peranya sebagai manajer hendaknya berperilaku membangun, karena keberhasilannya sangat tergantung pada kualitas kepemimpinannya dalam hal meningkatkan kinerja guru. Keefektifan kepemimpinan terletak pada tercapainya dua faktor,[14] yaitu: 1) Tujuan bersama (sekolah) sebagai suatu organisasi yang merupakan suatu sistem kerja sama yang di dalamnya terpolakan sistem pengaturan dan pembangunan tugas. 2) Terpenuhi kebutuhan anggotanya (guru) sebagai individu, sebagai pemimpin sekolah. Kepala sekolah mempunyai tugas yaitu merencanakan pengambilan keputusan.

Memiliki keleluasaan dalam mengatur segenap sumber daya yang dimilikinya supaya terjadi peningkatan mutu dan produktivitas yang signifikan dalam memberikan layanan belajar yang bermutu, Pemimpin harus memberikan pembinaan kepada bawahan agar dapat berkerja secara berdaya guna dan berhasil guna, sehingga pekerjaan yang dihasilkan mempunyai kualitas. Adanya pembinaan disiplin kerja oleh kepala sekolah terhadap tenaga pendidik, maka diharapkan tujuan-tujuan yang sudah direncanakan dapat berjalan dengan baik.

Sebagai pemimpin sekolah dengan kemampuan profesional manajemen pendidikan, kepala sekolah diharapkan dapat menyusun program sekolah yang efektif, menciptakan iklim sekolah yang kondusif, membangun unjuk kerja, memonitor dan menilai kegiatan sehari-hari guru serta dapat membimbing dan melakukan pembinaan kepada tenaga pendidik. Dalam melaksanakan pembinaan terhadap guru kepala sekolah harus lebih memahami karakter dari setiap individunya, karena setiap guru memiki karakter dan kebiasaan yang berbeda-beda. Perilaku guru yang dalam proses pembelajaran hanya sekedar menyampaikan materi tidak memperdulikan apakah peserta didik sudah memahami atau belum, tidak mengenal dan memahami kebutuhan peserta didiknya, kurang menguasai tentang perangkat pembelajaran, guru yang sering membolos, datang tidak tepat pada waktunya. Kondisi guru yang seperti itulah yang menjadi permasalahan disetiap lembaga pendidikan formal. Adanya guru yang mempunyai kinerja yang rendah, sekolah akan sulit untuk mencapai hasil seperti yang diharapkan. Kinerja akan tercapai ketika kepala sekolah melakukan komunikasi, koordinasi, dan pengawasan secara berkala.[15]

Berdasarkan latar belakang di atas, bahwa kinerja guru perlu diawasi dan di evaluasi apakah terjadi perubahan dalam meningkatkan mutu sekolah atau tidak, untuk itu dalam artikel ini akan berusaha menjelaskan secara konprehensif peran managerial kepala sekolah dalam fungsi cotrolling dan evaluasi terhadap kinerja guru. Tujuan dalam artikel ini untuk menjelaskan fungsi cotrolling dan evaluasi kepala sekolah terhadap kinerja guru.

\section{B. METODE PENELITIAN}

1. Metode Penelitian yang Digunakan

Penelitian ini menggunakan model penelitian lapangan yang bersifat Deskkriptif kualitatif. Penelitian deskriptif kualitatif merupakan jenis penelitian dengan proses memperoleh data bersifat apa adanya. Penelitian ini menggunakan metode kualitatif digunakan untuk mendeskripsikan tentang fungsi controlling dan evaluasi kepala sekolah terhadap kinerja Guru.

\section{Metode Pengumpulan Data}

Menggunakan wawancara dan dokumentasi. Wawancara yang digunakan dalam penelitian ini dengan mengajukan pertanyaan-pertanyaan testruktur karena peneliti menggunakan pedoman wawancara yang disusun secara sistemstis dan lengkap untuk mengumpulkan data yang dicari. Wawancara pada penelitian ini dilakukan kepada kepala sekolah SMPN I Lembar, wakil kepala sekolah dan guru kelas SMPN I Lembar. Dokumentasi digunakan untuk memperoleh data dalam bentuk tertulis maupun non-tulis. Dokumentasi dapat berupa vidio, rekaman, dan standar operasional rapat.

\section{Tempat Penelitian}

Penelitian ini bertujuan untuk mendapatkan gambaran dan informasi yang lebih jelas, lengkap serta memungkinkan dan mudah bagi peneliti untuk melakukan penelitian. Oleh karena itu, maka peneliti menetapkan lokasi penelitian adalah tempat dimana penelitian akan dilakukan. Dalam hal ini Tempat 
penelitian dilaksanakan di SMPN I Lembar sebagai tempat penelitian karena peneliti tertarik untuk meneliti peran kepala sekolah sebagai manajer dalam fungsi Controlling dan Evaluasi terhadap kinerja guru.

4. Subjek Penelitian

Subjek dalam penelitian ini adalah kepala sekolah SMPN I Lembar, wakil kepala sekolah, dan guru kelas SMPN I Lembar. Dalam penelitian ini menentukan informan dengan menggunakan teknik purposive, yaitu dipilih dengan pertimbangan dan tujuan tertentu, yang benar-benar menguasai suatu objek yang peneliti teliti.

\section{Teknik Analisis Data}

Ada tiga macam kegiatan dalam analisisi data kualitatif, terdiri atas, Pertama, reduksi data, reduksi data merujuk pada proses pemilihan, pemfokusan, penyederhanaan, abstraksi, dan pentransformasian data mentah yang terjadi dalam catatan catatan lapangan tertulis. Display data, langkah kedua dari kegiatan analisis data adalah model data. Model sebagai suatu kumpulan informasi yang tersusun yang membolehkan pendeskripsian kesimpulan dan pengambilan tindakan. Setelah informasi yang didapat dikumpulkan maka kemudian disusun agar mempermudah dalampenarikan kesimpulan. Ketiga, penarikan atau verifikasi kesimpulan, setelah dilakukan pengumpulan data dan menyusun data yang diperoleh dari lapangan, maka langkah selanjutnya ialah menarik kesimpulan. Kesimpulan didapat melalui analisis yang dilakukan oleh penulis dari data atau informasi.

\section{HASIL DAN PEMBAHASAN}

\section{Fungsi Controlling Kepala Sekolah Terhadap Kinerja Guru}

Fungsi kepala sekolah sebagai seorang pemimpim adalah memperhatikan dan mempraktikan fungsi kepemimpinan dalam kehidupan sekolah, yaitu sebagai berikut: 1) Berlaku adil terhadap semua bawahannya. Sebaliknya menciptakan semangat kebersamaan diantara mereka yaitu guru, sataf, dan para siswa; 2) Mampu memberikan sugesti maupun saran kepada semua bawahannya dalam melaksanakan tugas seperti guru, staf, dan siswa dalam rangka memlihara dan meningkatkan semangat rela berkorban, dan rasa kebersamaan dalam menjalankan tugas;3) Bertanggung jawab dan memberiakan dukungan kepada semua bawahannya dengan menyediakan apa yang menjadi kebutuhan dari bawahannyan; 4) Katalisator dalam arti mampu menimbulkan dan mengerakan semangat guru, staf, dan siswa dalam pencapaian tujuan yang telah ditetapkan; 5) Menciptakan rasa aman dilingkunagan sekolah; 6) Memberikan penghargaan dan pengakuan kepada setiap bawahanya yang dapat diwujudkan dalam berbagai bentuk seperti kenaikan pangkat, fasilitas, kesempatan mengikuti pendidikan, dan sebagainya.[16]
Peran kepala sekolah sebagai manajer yaitu sebagai pengelola semua sumber daya sekolah untuk dapat berjalan secara efektif dan efisien mencapai tujuan sekolah.[17] Pengawasan merupakan proses dasar yang secara esensial diperlukan oleh lembaga pendidikan.[18] Pengawasan juga berfungsi sebagai alat untuk memantau aktivitas kegiatan manajemen mulai dari memantau dan menilai perencanaan dan pelaksanaan, apakah terdapat kesalahan dan penyimpangan atau tidak, dan kemudian dilakukan perbaikan serta mencegah agar kesalahan dan penyimpangan tidak terulang kembali.[19]

Kepala sekolah dalam melaksanakan fungsi controlling dengan mengacu pada keberhasilan kepala sekolah yaitu berdasarkan tindakan yang dilakukan oleh kepala sekolah itu sendiri. Pengawasan (controlling) yaitu untuk mengawasi apakah gerakan dari organisasi ini sudah sesuai dengan rencana atau belum. Serta mengawasi penggunaan sumber daya dalam organisasi agar bisa terpakai secara efektif dan efisien tanpa ada yang melenceng dari rencana. Proses controlling terhadap kinerja organisasi penting dilakukan, karena tanpa adanya controlling yang dilakukan tidak akan diketahui sampai sejauhmana organisasi tersebut telah efektif melakukan perubahan menuju organisasi berkinerja tinggi. Bisa dikatakan bahwa controlling terhadap kinerja organisasi pada hakekatnya adalah sebuah usaha untuk mengetahui maupun mengukur tentang sejauh mana keberhasilan dari pada kinerja yang dihasilkan, apakah sudah dikatakan baik atau tidak. Dari controlling inilah bisa diketahui apa kekurangan dalam mewujudkan tujuan organisasi dan kemudian dapat dilakukan langkah-langkah intervensi yang dilakukan oleh pemimpin guna untuk memperbaiki kondisi yang ada.

Untuk mendapatkan data tentang peran kepala sekolah sebagai manajer dalam fungsi controlling terhadap kinerja guru di SMPN I Lembar, peneliti mengajukan pertanyaan kepada informan tentang bagaimana bentuk controlling yang di lakukan oleh kepala sekolah dalam meningkatkan kinerja guru di SMPN I Lembar.

Menurut H. Saidi menyatakan:

"sejak awal saya menjabat sebagai kepala sekolah SMPN I Lembar saya sudah menyusun langkah apa saja yang harus saya lakukan kedepannya salah satunya langkah yang ingin saya tempuh adalah dengan menerapkan sistem controlling terhadap kinerja guru. Dengan diterpakanya sistem tersebut kita dapat melihat dan mengetahui dengan jelas kinerja dari seseorang seperti hal yang biasa saya lakukan dalam hal pengaawasan terhadap bawahan saya diantaranya: (1) Melakukan pengawasan terhadap kedisplinan waktu; (2) Mengawasi guru yang sering absen sekolah; (3) Mengecek 
perangkat pemebelajaran; (4) Melihat cara guru membangun komunikasi dalam lingkungan sekolah, baik itu sesama guru maupun dengan siswa; (5) sarana dan prasarana sekolah. Karena dengan adanya sarana yang memadai mampu menunjang keberhasilan dalam melakukan pembelajaran. Poin-poin diatas merupakan hal yang sering sekali saya lakukan bahkan kadan-kadang setiap hari saya selau mengawasi tindakantindakan dari bawahan saya. Ini semua saya lakukan agar apa yang kami harapkan tidak melenceng dari harapan kami teruma saya sebagai pemimpin." (Wawancara 6 juli 2020)

Sistem controlling yang dilaksanakan adalah dengan mengadakan pemantauan secara rutin yang dilakukan oleh kepala sekolah. laporan dan tindak lanjut terhadap setiap guru baik dalam proses pembelajaran maupun dalam melaksanakan tugas-tugas dari kepala sekolah secara rutin dan terjadwal.

Demikian juga Menurut Idha Ketut Pijaksan, mengatakan:

"Pengawasan merupakan hal yang pasti yang dilakukan seorang pemimpin demi mencapai tujuan dari sebuah organisasi. Seperti halnya kepala sekolah SMPN I Lembar yang dimana beliau sangat rutin dalam melakukan pemantauan terhadap kinerja dari guru bahkan sering sekali beliau mengunjungi kelas-kelas hanya untu melihat apakah kelas tersebut ada gurunya atau tidak. Dan jika ditemukan ada kejanggalan yang beliau temukan, beliau senantiasa membimbing dan mendorong setiap individu kami agar memberikan kinerja yang terbaik terhadap lembaga. Bahka sering kali beliau menegur ketika ada kinerja yang kurang memuaskan beliau. Itu semua cara beliau dalam meningkatkan hasil kinerja kami sebagai tenaga pendidik di SMPN I Lembar ini." (Wawancara 29 juni 2020)

Kepala sekolah memiliki kepribadian yang baik serta tanggung jawab, terlihat jelas dari pengontrolan yang dilakukannya dan senantiasa memberi arahan ketiaka ditemukan guru-guru yang kurang profesional dalam halnya menjalankan tugasnya.

Menurut tenaga pendidik menyatakan bahwa:

"Kepala sekolah sebagai pemimpin memiliki peran yang sangat penting seperti dalam hal melakukan controlling terhadap kinerja guru. Kepala sekolah selalu memantau setiap akttivitas bawahannya selama dalam lingkungan sekolah dan memberika kritikan ketiaka tidak mampu dalam menjalankan tugas yang diberikan kepadanya. Selain melakukan pengawasan terhadap kinerja guru kepala sekolah senantiasa menggerakan seluruh warga sekolah baik guru, staff dan siswa. Menggerakan berarti melaksanakan setiap tugas-tugas yang sudah seharusnya dilaksanakan dan beliau selalu memperhatikan kinerja setiapa invidu, ini semua beliau lakukan hanya untuk menjaga agar apa yang sudah menjadi tujuan awala dapat berjalan sesuai dengan program-program yang sudah disusun sebelumnya." (Wawancara 8 juli 2020)

Sistem controlling yang dilaksanakan adalah dengan mengadakan pemantauan secara terus menerus yang dilakukan oleh kepala sekolah dimulai dari pengecekan kehadiran guru maupun kemampuan kinerja didalam kelas. Pemantauan maupun pengawansan yang dilakukan oleh kepala sekolah guna untuk menjaga kualitas para bawahannya agar tidak menghasilkan kinerja diluar dari perencanaan-perencanaan yang sudah ditetapkan sebelumnya. Pengawasan ataupun pengontrolan yang dilakukan oleh kepala sekolah ini berlaku kepada semua warga sekolah selama masi ada dalam lingkungan sekolah. Pemantauan maupun pengawasan yang dilakukan oleh kepala sekolah dilakukan secara terus menerus guna melihat sejauh mana tenaga pendidik menjalankan tugasnya, dan apabila ditemukan ada beberapa tenaga pendidik yang tidak memilki kinerja yang yang baik, maka disisnilah pera kepala sekolah untuk mengarahkan dan memeberi solusi atas apa yang menjadi kendala dari bawahannya. selain pemantauan yang rutin dilakukan, kepala sekolah juga menggerakan semua guru, staff, maupun siswa agar menjalankan apa yang menjadi tugas mereka masingmasing. Pemantuan yang dilakukan terjadi setiap guru baik dalam proses pembelajaran maupun dalam melaksanakan tugas-tugas dari kepala sekolah secara rutin dan terjadwal.

Kepala sekolah merupakan badan fungsional yang diberikan tugas tambahan sebgai pemimpin dalam sekolah yang dimana terjadinya interaksi antara kepala sekolah dengan guru, maupun ineteraksi yang terjadi antara guru yang memberi pelajaran maupun murid yang menerima. Seorang manajer harus memiliki sikap profesional yang tinggi karena pada dasanya peran dari seorang manajer adalah sebagai perencana, organisator, pemimpin, dan seorang pengendali jalannya sebuah lembaga. Keberadaan seorang manajer dalam sebuah organisasi sangat diperlukan karena kepala sekolah adalah motor penggerak dari sebuah organisasi pendidikan.

Dengan demikian kepala sekolah rutin melakukan Controlling terhadap kinerja guru, kepala sekolah sering menekankan agar semua bawahannya lebih memperhatikan kedisiplinan dalam menjalakan tugasnya sebagai pendidik. Selain itu, melakukan kontrol secara rutin dalam memantau kinerja guru dan 
memberikan arahan dan masukan ketika ada kinerja yang tidak memuaskan. Hal tersebut sejalan dengan penelitian yang mengatakan bahwa kepala sekolah mampu menjalankan tugasnya sebagai supervisor dan administrasi dengan baik.[7] Penerapan fungsi controlling dilaksanakan dengan pemantauan pada kesiapan tenaga pendidik dalam mempersiapkan silabus pembelajaran, memantau pelaksanaan proses pembelajaran di kelas, melakukan kegiatan supervisi kepala sekolah dan kegiatan kelompok kerja guru setiap satu bulan.[20]

\section{Fungsi Evaluasi Kepala Sekolah Terhadap Kinerja Guru}

Evaluasi kinerja guru memiliki 2 fungsi utama yaitu: Pertama, untuk menilai kemampuan guru dalam menerapkan semua kompetensi dan keterampilan yang diperlukan pada proses pembelajaran, pembimbingan, atau pelaksanaan tugas tambahan yang relevan dengan fungsi sekolah/madrasah. Dengan demikian, profil kinerja guru sebagai gambaran kekuatan dan kelemahan guru akan teridentifikasi dan dimaknai sebagai analisis kebutuhan atau audit keterampilan untuk setiap guru, yang dapat dipergunakan sebagai basis untuk merencanakan PKB. Kedua, untuk menghitung angka kredit yang diperoleh guru atas kinerja pembelajaran, pembimbingan, atau pelaksanaan tugas tambahan yang relevan dengan fungsi sekolah/madrasah yang dilakukannya pada tahun tersebut. Kegiatan penilaian kinerja dilakukan setiap tahun sebagai bagian dari proses pengembangan karir dan promosi guru untuk kenaikan pangkat dan jabatan fungsionalnya.[21]

Evaluasi kinerja mempunyai banyak manfaat, karena dapat digunakan sebagai alat dalam berbagai pengambilan keputusan. Manfaat penilaian kinerja karyawan antara lain dapat dipergunakan sebagai dasar untuk pembayaran upah, gaji, bonus dan sebagai alat dalam pengawasan penugasan pekerjaan, penentuan latihan dan pengembangan, sebagai alat pemberi rangsangan dan dalam pemberian nasihat-nasihat kepada karyawan.[22]

Menurut Saidi menyatakan, bawah

"Sebelum dilakukannya evaluasi ada program perencanaan-perencanaan yang kita lakukan terlebih dahulu. Dan program-program inilah nantinya yang harus kita evaluasi. perencanaan atau planing merupakan susunan awal keberhasilan untuk mencapai tujuan dari sekolah. Begitu pula dalam bentuk pembinaan kinerja guru, agar apa yang sudah direncanakan sebelumnya bisa tercapai dengan semestinya. dan Berkaitan dengan perencanaan pembinaan para guru itu biasanya kita memasukkan perencanaan pembinaan guru ke dalam perencanaan jangka panjang. Pembinaan guru masuk dalam program strategis peningkatan, pengembangan pendidik dan tenaga kependidikan. Dengan mengacu pada perencanaan jangka panjang tersebut kemudian disusun rencana tahunan untuk pembinaan guru yang terdiri dari pembinan yang bersifat harian, pekanan, bualanan, dan tahunan denagan berbagai kegiatan untuk meningkatkan kinerja guru. Dari hasil perencanaan inilah yang nantinya akan di evaluasi baik itu evaluasi tahunan maupun evaluasi harian, pekanan, maupun bulanan. Dengan adanya evaluasi ini dapat mengukur sejauh mana kinerja yang diihasilkan oleh para guru apakah sesuai dengan program yang telah disusun ataukah tidak. Dari sinilah kita bisa melihat dimana saja kekurangannya. dari kekurang itulah nantinya akan diberikan solusi dan masukan yang sifatnya membangun oleh kepala sekolah agar pada perencanaan berikutnya bisa berjalan sesuai dengan tujuan yang sudah ditetapkan sebelumnya." (Wawancara 6 juli 2020)

Dalam menjalankan fungsi evaluasi terhadap kinerja guru dilakukanya evaluasi ada perencanaan yang dilakukan terlebih dahulu. Hasil Dari perencanaanperencanaan inilah yang nantinya akan di evaluasi baik itu evaluasi tahunan, maupun evaluasi yang bersifat harian, pekakanan, bulanan. Evaluasi ini merupakan komponen terpenting dalam meningkatkan evaluasi kinerja guru. Karena dengan dilakukannya evaluasi dapat diukur sejauhmana kinerja kinerja yang dihasilkan.

Menurut tenaga pendidik menyatakan,

"Evalusi merupakan hal yang pasti yang kita lakukan karena dengan melakukan evaluasi disitu kita dapat melihat apakah kinerja kita sudah sesuai dengan yang direncanakan sebelumnya ataukah tidak sesuai. Dan beliau juga mengatakan bahwa untuk mencapai kinerja yang baik harus dilandasi oleh perencanaan yang dilakukan yang dimana tujuan utama dari perencanaan itu sendiri adalah untuk meningkatkan kinerja guru dalam kehadiran mengajar maupun bersikap." (wawancara 8 juli 2020)

Dalam menjalankan fungsi evaluasi terhadap kinerja guru, dilakukanya evaluasi pada berbagai perencanaan yang dilakukan terlebih dahulu, dalam perencanaan yang dilakukakan oleh kepala sekolah maupun yang dilakukan oleh lembaga berupa perencanaan jangka panjang. Perencanaan jangka panjang inilah disusun sedemikian rupa berkaitan dengan tujuan yang ingin dicapai oleh lembaga. Mengacu pada perencanaan jangka panjang juga dibuat perencanaan tahunan, bulanan, dan pekanan.

Hasil dari perencanaan-perencanaan inilah yang nantinya akan di evaluasi baik itu evaluasi tahunan, 
maupun evaluasi yang bersifat harian, pekakanan, bulanan. Evaluasi tidak hanya dilakukan oleh kepala sekolah untuk menilai kinerja dari para pendidik, namun para pendidik juga melakukan evaluasi secara rutin terhadap siswanya agar apa yang menjadi tujuan dalam rancangan pemebelajaran bisa berjalan sesuai yang diharapkkan. Evaluasi juga merupakan komponen terpenting dalam meningkatkan kinerja guru. Karena dengan dilakukannya evaluasi dapat diukur sejauhmana kinerja yang dihasilkan. Jika dalam melakukan evaluasi tidak sesuai dengan perencanaan awal maka disisnilah peran kepala sekolah sebagai manajer dalam memberikan dorongan dan motivasi kepada semua bawahannya dan memberikan pengarahan dan solusi terhadap setiap permasalahan yang dihadapi bawahannya.

Hasil evaluasi oleh kepala sekolah terhadap kinerja guru memiliki beberapa hal yaitu permasalahan pada siswa dan guru terutama pada mutu pendidikan. Mutu pendidikan di sekolah tersebut belum maksimal karena minimnya fasilitas dan wawasan guru dalam memberikan pembelajaran yang baik kepada guru. Sementara, evaluasi dilakukan oleh kepala sekolah dengan melakukan koordinasi dengan para wakil sehingga apabila terdapat permasalahan akan dapat dicarikan solusi yang tepat. Evaluasi yang dilakukan oleh kepala sekolah, yayasan juga melakukan evaluasi rutin, evaluasi yang dilakukan oleh yayasan untuk melihat kemajuan dan perkembangan yang ada di sekolah.

Evaluasi terhadap kinerja memiliki indikator yaitu evaluasi jagka panjang, menengah dan pendek. Terkait evaluasi kinerja guru termasuk kinerja jangka pendek karena berkaitan dengan pelayanan pembelajaran. Evaluasi jangka panjang berhubungan dengan mutu pendidikan di sekolah mulai kurikulum, prestasi, mutu, pengembangan komptenesi guru dan pengembangan fasilitas. Semntara evaluasi jangka menengah berhubungan dengan mutu pembelajaran sementara evaluasi jangka pendek berkaitan kinerja guru dalam memberikan pelayanan pembelajaran. Beberapa hasil evaluasi, kepala sekolah lebih banyak memberikan arahan dan rekomendasi perbaikan mutu sekolah.

Kepala sekolah selalu memberikan arahan mengenai tugas yang harus diselesaikan dalam memeperbaiki kinerja guru agar dapat meningkatkat secara signifikan. Selain itu, kepala sekolah menyarankan untuk selalu ikut berpartisipasi dalam setiap kegiatan membuat adanya kemajuan yang dialami lembaga pendidikan baik mengenai kinerja guru maupun prestasi baik sekolah maupun siswa itu sendiri. Pemanfaatan dalam mengikut sertakan anggota dalam setiap kegiatan disesuaikan dengan posisi atau kemampuan yang dimilikinya hal inibertujuan agar dapat menyelesaikan tujuan dengan baik, pentingnya bagi pencapaian tujuan bersama kepala sekolah sebagai manajer membimbing setiap anggota. Selain itu kepala sebagai manajer juga menciptakan displin baik waktu maupun kerja, kepala sekolah tidak memberikan hukuman sebagai alat untuk memaksa anggota bekerja, namun kepala sekolah memilih kepercayaan dan tanggung jawab anggota untuk dapat sanggup bekerja dengan apik.

Pemberian tugas dan pengarahan terlebih dahulu mengenai kejelasan tugas dan mengenai tugas yang harus dikerjakan oleh guru atau staff merupakan tahap yang selalu diberikan dengan tujuan untuk selalu mengingatkan agar tugas yang dikerjakan sesuai dengan tujuan lembaga. Perhatian selalu kepala sekolah berikan, karena guru maupun staff juga sangat senang ketika mendapatkan perhatian penuh dari kepala sekolah yakni mengonntrol kerja, selain itu kepala sekolah tidak sungkan untuk memberikan pujian kepada guru, staff maupun siswa yang taat dengan peraturan dan memberikan apresiasi atas hasil kerjanya, dalam hal ini kepala sekolah sering memberikan imbalan berupa insentif, namun lebih sering berupa ucapan atau pujian. Hal seperti ini dilakukan semata untuk membuat individu yang lain semangat dan termotivasi untuk berlomba-lomba menjadi yang lebih baik lagi.

Semakin sering memberikan arahan maka akan semakin baik pula kinerja guru.[23] Kinerja guru dapat dilihat dan diukur berdasarkan spesifikasi/kriteria kompetensi yang harus dimiliki oleh setiap guru, dapat ditampilkan melalui penguasaan kompetensi pedagogik, profesional, kepribadian dan sosial.[24] Evaluasi kinerja guru dapat dijadikan sebagai upaya untuk penjaminan mutu sekolah, terkait dengan aspek (1) pengembangan pribadi, (2) pemelajaran, (3) peningkatan kemampuan profesional, dan (4) interaksi sosial dengan stakeholder.[25]

\section{TEMUAN ATAU DISKUSI}

Upaya kepala sekolah dalam menjalankan fungsinya dalam bidang controlling terhadap kinerja dapat dikatakan terlaksana dengan baik dengan dibuktikan terlaksananya pelaksanaan evaluasi yang telah dilakukan dengan baik oleh semua guru. Evaluasi merupakan sebuah proses pengumpulan data untuk menentukan sejauh mana, dalam hal apa, dan bagaimana tujuan pendidikan sudah tercapai. Proses evaluasi bukan sekedar mengukur sejauh mana tujuan tercapai, tetapi digunakan untuk membuat keputusan. Hasil evaluasi dilakukan sebagai bahan pertimbangan untuk membuat program selanjutnya, selain itu juga dapat digunakan sebagai bahan pertimbangan dan intropeksi diri agar kedepannya dapat dilakukan perbaikan-perbaikan dalam upaya peningkatan kinerja guru.

Fungsi kepala sekolah sebagai controling terhadap kinerja guru meliputi kegiatan:

1. Melakukan pengawasan terhadap kedisplinan waktu

2. Mengawasi guru yang sering absen sekolah

3. Mengecek perangkat pemebelajaran 
4. Melihat cara guru membangun komunikasi dalam lingkungan sekolah, baik itu sesama guru maupun dengan siswa

5. Mengecek sarana dan prasarana sekolah

Fungsi evaluasi kepala sekolah terhadap kinerja guru meliputi: evaluasi tahunan maupun evaluasi harian, pekanan, maupun bulanan.

\section{E. SIMPULAN DAN SARAN}

Hasil penelitian ini menunjukkan bahwa fungsi controlling kepala sekolah yaitu melakukan pengawasan terhadap kedisplinan waktu, mengawasi guru yang sering absen sekolah, mengecek perangkat pemebelajaran, melihat cara guru membangun komunikasi dalam lingkungan sekolah, baik itu sesama guru maupun dengan siswa sarana dan prasarana sekolah. Karena dengan adanya sarana yang memadai mampu menunjang keberhasilan dalam melakukan pembelajaran. Untuk mengevaluasi kinerja guru, peran kepala sekolah mengacu pada prinsip evaluasi yaitu menilai kemampuan guru dalam menerapkan semua kompetensi dan keterampilan yang diperlukan pada proses pembelajaran, pembimbingan, atau pelaksanaan tugas tambahan yang relevan dengan fungsi sekolah/madrasah. Jadi kepala sekolah memiliki tugas untuk menilai kinerja baik buruknya bawahannya dan memiliki peran penting untuk meningkatkan mutu sekolah dengan mengevaluasi secara berkala.

Hasil penelitian ini mneyarankan bahwa kepala sekolah harus lebih memperhatikan kembali kemampuan dari para guru maupun staff atau seluruh warga sekolah dengan cara meningkatkan kegiatan pelatihan-pelatihan guna untuk meningkatkan kinerja dan kemampuan lembaga sekolah agar apa yang menjadi tujuan sebelumnya bisa sesuai dengan yang diharapkan. Kepala sekolah harus lebih meningkatkan lagi pengawasan terhadap kinerja guru, agar tidak terjadinya penyimpangan dari program-program yang telah direncanakan. Kepala sekolah harus mengapresiasi dengan cara pemberian reword bagi guru yang memilki kinerja yang bagus.

\section{UCAPAN TERIMA KASIH}

Penulis mengucapkan terima kasih kepada semua pihak yang telah memberikan dana dan data sehingga pelaksanaan penelitian dapat dilakukan dnegan baik, serta yang senantiasa memberikan bimbingan, nasehat, dan motivasi kepada penulis sehingga penelitian ini selesai dengan baik.

\section{DAFTAR RUJUKAN}

[1] I. Dwi Chayani, "Peran Kepala Sekolah Sebagai Manajer Dalam Upaya Peningkatan Kompetensi Guru di SMA Unggulan Amanatul Ummah Surabaya," Inspirasi Manaj. Pendidik., vol. 2, no. 2, 2016.
[2] Y. I. Rosyadi and P. Pardjono, "Peran kepala sekolah sebagai manajer dalam meningkatkan mutu pendidikan di smp 1 cilawu garut," J. Akuntabilitas Manaj. Pendidik., vol. 3, no. 1, pp. 124-133, 2015.

[3] C. Z. H. Marzuwan and S. Ibrahim, "Kepemimpinan Kepala Sekolah Sebagai Manajer Dalam Peningkatan Mutu Pendidikan di SMA Negeri 1 Meureudu," J. Adm. Pendidik. Progr. Pascasarj. Unsyiah, vol. 4, no. 3, 2016.

[4] M. Nur, C. Z. Harun, and S. Ibrahim, "Manajemen Sekolah Dalam Meningkatkan Mutu Pendidikan Pada Sdn Dayah Guci Kabupaten Pidie,” J. Adm. Pendidik. Progr. Pascasarj. Unsyiah, vol. 4, no. 1, 2016.

[5] M. Fitrah, "Peran kepala sekolah dalam meningkatkan mutu pendidikan," J. Penjaminan Mutu, vol. 3, no. 1, pp. 31-42, 2017.

[6] A. Adrijanti and H. P. Rahayu, "Peran Kepala Sekolah Sebagai Manajerial Dan Motivasi Tinggi Untuk Menciptakan Mutu Pendidikan (Studi Kasus Di Sman 1 Gresik)," J. Ilm. Kegur. dan Ilmu Pendidik., vol. 9, no. 1, pp. 19-36, 2019.

[7] H. Hamidi, N. Nuzuwar, and I. Nurmal, "Peran Kepala Sekolah Sebagai Administrator dan Supervisor," Alignment J. Adm. Educ. Manag., vol. 2, no. 1, pp. 3947, 2019.

[8] L. L. Byars, L. L. Byars, and L. W. Rue, Supervision: Key link to productivity. Irwin Professional Publishing, 1990.

[9] M. A. A. A. Prabu, "Manajemen Sumber Daya Manusia Perusahaan, Edisi Pertama, PT," Remaja Rosdakarya, Bandung, 2001.

[10] H. Nawawi, Administrasi pendidikan. PT Toko Gunung Agung, 1995.

[11] H. B. Uno, "Teori motivasi \& pengukurannya," Jakarta Bumi Aksara, 2008.

[12] S. Soedijarto, "Upaya Percepatan Peningkatan Kualifikasi Pendidikan dan Tenaga Kependidikan Pendidikan Non Formal (Ptk-pnf)," J. Ilm. Visi, vol. 3, no. 1, pp. 30-33, 2008.

[13] A. H. S. Hermino, Kepemimpinan Pendidikan di Era Globalisasi. Pustaka Pelajar, 2014.

[14] V. Rivai, Manajemen sumber daya manusia utnuk perusahaan: dari teori ke praktik. PT RajaGrafindo Persada, 2004.

[15] A. Rukmana, "Kualitas Kinerja Guru Sekolah Dasar," $J$. Adm. Pendidik., vol. 7, no. 1, 2008.

[16] E. Mulyasa, "Menjadi guru profesional," Bandung: Remaja Rosdakarya, 2005.

[17] S. Hidayat and M. P. S. Asroi, "Implementasi dalam Praktik Pendidikan di Indonesia," Tanggerang: Pustaka Mandiri, 2013.

[18] N. Fatah, "Landasan Manajemen Pendidikan Bandung: Remaja Rosdakarya," 1996.

[19] F. Fitriani and A. Sakban, "Penerapan Pendidikan Karakter Terhadap Efektifitas Penggunaan Kurikulum 2013 Dalam Persepektif Moral Bangsa di SMA Nurul Jannah NW Ampenan," Civ. Pendidikan-PenelitianPengabdian Pendidik. Pancasila dan Kewarganegaraan, vol. 6, no. 1, pp. 1-7, 2018.

[20] N. R. Arumsari, "Penerapan Planning, Organizing, Actuating, Dan Controlling di UPTD Dikpora Kecamatan Jepara,” J. Ekon. dan Bisnis Kontemporer, vol. 3, no. 2, 2017. 
[21] A. Jaedun, "Evaluasi kinerja profesional guru," Makalah.Jaedun@yahoo.com. hal1-16.html, 2009.

[22] L. Jason, W. Billows, D. Schnopp-Wyatt, and C. King, "Reducing the illegal sales of cigarettes to minors: Analysis of alternative enforcement schedules," J. Appl. Behav. Anal., vol. 29, no. 3, pp. 333-344, 1996.

[23] S. Setiyati, "Pengaruh kepemimpinan kepala sekolah, motivasi Kerja, dan budaya sekolah terhadap kinerja guru,” J. Pendidik. Teknol. dan Kejuru., vol. 22, no. 2, pp. 200-206, 2014.

[24] U. Iskandar, "Kepemimpinan kepala sekolah dalam peningkatan kinerja guru," J. Visi Ilmu Pendidik., vol. 10, no. 1, 2013.

[25] C. Triatna, "Evaluasi Kinerja Guru dan Upaya Penjaminan Mutu Sekolah,” J. Adm. Pendidik., vol. 5, no. $1,2007$. 